\title{
PEMBIAYAAN MUDHARABAH TERHADAP RETURN ON INVESTMENT: Studi Kasus pada Bank Mandiri Syariah Kuningan
}

\author{
Dewi Fatmasari, Rita Kusumadewi dan Indri Nur Oktavianti \\ Fakultas Syariah dan Ekonomi Islam \\ Institut Agama Islam Negeri Syekh Nurjati Cirebon \\ e-mail:dewifatmasari73@gmail.com, kusumadewi.ryta@gmail.com \\ danindrinur.oktavianti@yahoo.co.id
}

\begin{abstract}
The purpose of this study to determine how much revenue Mudharabah, to determine the level of return on investment, and to know how big the influence of financing on the return on investment from year to year for the last 7 years.This study uses a quantitative descriptive approach. The object of this study is the Bank Syariah Mandiri Kuningan. This type of research is a study that used the figure, from the collection of data, the interpretation of such data, as well as the appearance of the results. Quantitative research was also accompanied by tables, graphs, charts, drawings or other views. Based on the results of research that assisted with SPSS 21.0, using Simple Linear Regression to produce $Y=-1232+0,554 X$ interpreted in a positive relationship between financing is the return on investment, with a correlation of 0.703, which means a very strong relationship, and the coefficient of determination 0.494 which means the effect of financing the return on invesment is $49.4 \%$ while the remaining $50.6 \%$ is influenced by other factors not examined in this study.
\end{abstract}

Keywords: Mudharabah, Return On Investment, Islamic Banking.

\begin{abstract}
Abstrak
Tujuan penelitian ini untuk mengetahui seberapa besar pendapatan bagi hasil pembiayaan mudharabah, untuk mengetahui tingkat return on investment, dan untuk mengetahui seberapa besar pengaruh pembiayaan mudharabah terhadap return on investment dari tahun ke tahunnya selama 7 tahun terakhir. Penelitian ini menggunakan pendekatan deskriptif kuantitatif. Objek penelitian ini yaitu pada Bank Syariah Mandiri Kuningan. Jenis penelitian yang digunakan merupakan penelitian yang menggunakan angka, mulai dari pengumpulan data, penafsiran terhadap data tersebut, serta penampilan dari hasilnya. Penelitian kuantitatif juga disertai dengan tabel, grafik, bagan, gambar atau tampilan lain. Berdasarkan hasil penelitian yang dibantu dengan program SPSS 21.0, dengan menggunakan uji Regresi Linier Sederhana dengan menghasilkan $Y=-1.232+0,554 X$ diinterpretasikan adanya hubungan positif antara pembiayaan mudharabah dengan return on investment, dengan korelasi sebesar 0,703 yang berarti hubungannya sangat kuat, dan koefisien determinasi 0,494 yang dapat diartikan pengaruh pembiayaan mudharabah terhadap return on investent adalah 49,4\% sedangkan sisanya sebesar 50,6\% dipengaruhi oleh faktor lain yang tidak diteliti dalam penelitian ini.
\end{abstract}

Kata Kunci: Mudharabah, Return On Investment, Bank Syariah. 


\section{PENDAHULUAN}

Pendirian Bank Syariah yang berlandaskan syariat Islam merupakan perwujudan dari pengembangan kegiatan bisnis serta upaya menunjang pencapaian laba bank secara wajar dan mendorong pemberdayaan ekonomi melalui penyediaan produk dan jasa Bank Syariah. Dengan alasan bank syariah dapat diterima dengan baik oleh konsumen. Bank Syariah merupakan bank yang dalam sistem operasionalnyatidak menggunakan sistem bunga, akan tetapi menggunakan prinsip dasar sesuai dengan syariah Islam. Dalam menentukan imbalannya, baik imbalan yang diberikan maupun diterima, bank syariah tidak menggunakan sistem bunga, akan tetapi menggunakan konsep imbalan sesuai dengan akad yang diperjanjikan. ${ }^{1}$

Salah satu produk dari Bank Syariah adalah Pembiayaan Mudharabah. Pembiayaan mudharabah adalah akad perjanjian antara dua belah pihak atau lebih untuk melakukan kerjasama usaha. Satu pihak akan menempatkan modal sebesar $100 \%$ yang disebut dengan shahibul maal, dan pihak lainnya sebagai pengelola usaha, disebut dengan mudharib. Bagi hasil dari usaha yang dikerjasamakan dihitung sesuai dengan nisbah yang disepakati antara pihakpihak yang bekerja sama. $^{2}$

Salah satu alat untuk menilai kinerja bank syariah adalah dengan menggunakan Return On Investment. Return on Invesment merupakan alat untuk mengukur tingkat kembalian investasi yang telah dilakukan oleh suatu perusahaan, baik dengan menggunakan total aktiva yang dimiliki oleh perusahaan tersebut maupun dengan menggunakan dana yang berasal dari pemilik (sendiri). Salah satu cara untuk menghitung ROI dilakukan dengan cara laba bersih (earning after tax) dibagi dengan total aktiva. Dengan mengetahui rasio ini bisa dinilai apakah perusahaan efisien

\footnotetext{
${ }^{1}$ Ismail, Perbankan Syariah (Jakarta: Kencana, 2010), 34.

${ }^{2}$ Ismail, Perbankan Syariah, 83.
}

memanfaatkan aktivanya dalam kegiatan operasional perusahaan. Semakin tinggi ROI semakin efektif dalam menggunakan aktiva untuk memperoleh pendapatan. ${ }^{3}$

Kemampuan Bank dalam menghasilkan profit akan bergantung pada kemampuan manajemen bank yang bersangkutan dalam mengelola aset dalam liabilitas yang ada, serta secara kuantitatif probitabilitas dapat dinilai dengan menggunakan Gross Pofit Margin, Net Profit Margin, Return On Investment. Pada penelitian ini penulis menghitung tingkat profitabilitas dengan menggunakan Return On Investment (ROI) karena dengan menggunakan ROI bisa memperhitungkan bagaimana kemampuan manajemen bank dalam memperoleh laba secara keseluruhan dan ROI merupakan alat penilaian profitabilitas terbaik dalam penilaian tingkat kesehatan bank yang digunakan oleh Bank Indonesia sebagai pemegang otoritas perbankan.

Pembiayaan bagi hasil dalam prakteknya dapat berupa pembiayaan mudharabah. Pembiayaan mudharabah adalah akad kerjasama usaha antara dua pihak di mana pihak pertama (pemilik dana) menyediakan seluruh dana, sedangkan pihak kedua (pengelola dana) bertindak selaku pengelola, dan keuntungan usaha dibagi di antara mereka sesuai kesepakatan sedangkan kerugian finansial hanya ditanggung oleh pengelola dana. ${ }^{4}$ Sebagai salah satu produk penyaluran dana bank syariah pembiyaan mudharabah tentu memberikan kontribusi terhadap perolehan keuntungan bank syariah dari perolehan bagi hasilnya. Yang pada akhirnya dapat meningkatkan perolehan profitabilitas bank syariah. Untuk itu maka penulis merasa perlu untuk mengkaji lebih dalam lagi mengenai 1) Bagaimana Pembiayaan Mudharabah pada Bank

\footnotetext{
${ }^{3}$ Www.Ekonomi.kabo.biz/2012/01/return-oninvestment-roi.html/m=1. Diakses pada 02 April 2016.

${ }^{4}$ Fatwa Dewan Syariah Nasional No. 7 tentang Mudharabah.
} 
Mandiri Syariah KCP Kuningan? 2) Bagaimana Return On investment pada Bank Mandiri Syariah KCP Kuningan? 3) Bagaimana Pengaruh Pembiayaan Mudharabah terhadap Return On Investment pada Bank Mandiri Syariah KCP Kuningan?

\section{LITERATURE REVIEW}

Penelitian tentang pembiayaan mudharabah terhadap return on investment bukanlah suatu yang baru. Berikut beberapa karya yang terdokumentasikan terkait permasalahan yang dikaji, yaitu pertama, penelitian yang dilakukan oleh Arifin. ${ }^{5}$ Penelitian ini memiliki perbedaan terletak pada jumlah variabel yang digunakan. Hipotesis dalam penelitian ini Margin Murabahah berpengaruh positif terhadap Return On Investment, bagi hasil atas pembiayaan berpengaruh positif terhadap tingkat return on investment, margin murabahah dan bagi hasil atas pembiayaan secara bersama-sama berpengaruh positif terhadap tingkat return on investment.

Dan kedua, penelitian yang dilakukan oleh Imas Purnaningsih, ${ }^{6}$ tentang "Pengaruh Tingkat Pendapatan Bagi Hasil Pembiayaan Mudharabah dan Pembiayaan Musyarakah Terhadap Profitabilitas pada Bank Muamalat Indonesia Tbk." Dalam penelitian ini Hasil Penelitiannya Adalah Pembuktian dari hasil pengujian signifikansi secara menyeluruh (Uji F), Pendapatan bagi Hasil pembiayaan Mudharabah dan Pembiayaan Musyarakah secara bersamasama berpengaruh signifikan secara simultan terhadap profitabilitas. Sehingga dapat disimpulkan tidak ada perbedaan

\footnotetext{
${ }^{5}$ Arifin, "Pengaruh Margin Murabahah dan Bagi Hasil atas Pembiayaan Terhadap Tingkat Return On Investment pada perbankan Syariah". (Skripsi, Fakultas Syari'ah dan Hukum UIN Sunan Kalijaga Yogyakarta, 2010).

${ }^{6}$ Imas Purnaningsih, "Pengaruh Tingkat Pendapatan Bagi Hasil Pembiayaan Mudharabah dan Pembiayaan Musyarakah Terhadap Profitabilitas pada Bank Muamalat Indonesia Tbk". (Skripsi, Universitas Kuningan, 2012).
}

pengaruh pendapatan bagi hasil mana yang lebih signifikan terhadap profitabilitas, dikarenakan kedua pendapatan bagi hasil baik yang berasal dari pembiayaan Mudharabah maupun pembiayaan musyarakah sama-sama berpengaruh positif dan signifikan terhadap profitabilitas.

Dari kedua topik penelitian yang telah dipaparkan di atas, terdapat perbedaan dan persamaan dari judul yang diteliti mengenai Pengaruh Pembiayaan Mudharabah terhadap Return On Investment.

\section{METODOLOGI PENELITIAN}

Penelitian ini cenderung berdasarkan pada paradigma penelitian Kuantitatif. Penelitian Kuantitatif merupakan metode untuk menguji teori-teori tertentu dengan cara meneliti hubungan antar variabel. Variabelvariabel ini diukur (biasanya dengan instrumen penelitian) sehingga data-data yang terdiri dari angka-angka dapat di analisis berdasarkan prosedur statistik. ${ }^{7}$ Tujuan dari penelitian ini adalah untuk memperoleh gambaran mengenai Pembiayaan Mudharabah dan menguji hipotresis mengenai pengaruh Pembiayaan Mudharabah terhadap Return On Invesment.

Penelitian ini dimaksudkan untuk menguji hipotesis dengan menggunakan perhitungan statistik. Sehingga metode penelitian yang digunakan adalah metode verifikatif. Dengan menggunakan metode verifikatif akan diketahui signifikansi antara variabel yang diteliti sehingga menghasilkan kesimpulan yang akan memperjelas gambaran mengenai objek yang diteliti. Disamping itu, untuk memperoleh data secara terperinci dan baik, maka peneliti menggunakan wawancara (interview) adalah proses memperoleh keterangan untuk tujuan penelitian dengan cara tanya jawab, sambil bertatap muka antara si penanya atau pewancara dengan si penjawab atau responden dengan menggunakan alat yang

${ }^{7}$ Juliansyah, Metodologi Penelitian (Jakarta: Kencana Prenada Media Group, 2010), 38. 
dinamakan interview guide (pemanduan wawancara) serta berbagai dokumentasi yang ada dan yang dibutuhkan. ${ }^{8}$

Untuk memperoleh data yang diperlukan dalam penelitian ini maka penulis menggunakan metode pengumpulan data, yaitu pertama, Penelitian Lapangan. Penelitian lapangan ini dilakukan dengan mendapatkan mempelajari dan menganalisa dokumen atau catatan-catatan perbankan yang berhubungan dengan penelitian ini.

Kedua, Penelitian Kepustakaan. Penelitian ini dilakukan baik secara library research maupun internet research untuk menambah wawasan dan informasi tentang masalah yang dikaji, yang dilaksanakan dengan maksud untuk memperoleh datadata pendukung data-data sekunder yang diperoleh dari objek penelitian serta referensi-referensi lainnya yang berkaitan dengan penelitian ini.

Ketiga, Observasi. Observasi adalah teknik pengumpulan data yang dilakukan melalui suatu pengamatan, dengan disertai pencatatan terhadap keadaan atau perilaku objek sasaran. Pelaksanaan Observasi dapat dilakukan dengan tiga cara yaitu observasi langsung, observasi tidak langsung, dan observasi partisipasi. Observasi langsung adalah observasi yang dilakukan oleh peneliti terhadap objek yang diteliti secara langsung (tanpa perantara). Observasi tidak langsung adalah observasi yang dilakukan oleh peneliti terhadap suatu objek melalui perantara, yaitu dengan alat atau cara tertentu. Observasi yang ketiga adalah observasi partisipan, yaitu observasi yang dilakukan oleh peneliti dengan cara melibatkan diri atau ikut serta dalam kegiatan yang dilaksanakan oleh individu atau sekelompok orang yang menjadi objek pengamatan. $^{9}$

\footnotetext{
${ }^{8}$ Nur Asnawi dan Masyhuri, Metodologi Riset Manajemen Pemasaran (Malang: UIN-Malang Press, 2009), 163.

${ }^{9}$ Maman Abdurahman, Analisis Korelasi, Regresi, dan Jalur dalam Penelitian (Bandung: CV Pustaka Setia, 2011), 12.
}

Untuk memperoleh data yang dibutuhkan, penulis menggunakan teknik observasi yaitu dilakukan dengan cara mengamati dan mencatat secara sistematik terhadap gejala yang tampak pada objek penelitian, baik secara langsung ataupun tidak langsung. ${ }^{10}$

Penelitian Survey, Penelitian survey cukup banyak digunakan untuk pemecahan masalah perilaku organisasi termasuk kepentingan perumusan kebijakasanaan sumber daya manusia. Tujuan utamanya ialah mengumpulkan informasi tentang variabel dari sekelompok objek (populasi). Survey dengan cakupan seluruh populasi (objek) disebut sensus. Adapun survey yang mempelajari sebagian populasi dinamakan sampel survei. Untuk kepentingan perilaku organisasi, survey biasanya mengungkap permasalahan yang berkenaan dengan berapa banyak karyawan yang mendaftar dan diterima di suatu perusahaan? Berapa jumlah karyawan rata-rata dalam satu cabang? Berapa banyak karyawan yang telah memenuhi kualifikasi yang telah ditentukan? Pertanyaan kuantitatif seperti ini diperlukan sebagai dasar perencanaan dan pemecahan masalah sumber daya manusia di perusahaan. Pada tahap selanjutnya dapat pula dilakukan perbandingan atau analisis hubungan antara variabel tersebut. ${ }^{11}$

Sumber data dalam penelitian ini dikelompokkan menjadi dua bagian, yaitu: Data Primer, yaitu data yang langsung diperoleh dari sumber data pertama di lokasi penelitian atau objek penelitian yaitu di Bank Mandiri Syariah KCP Kuningan. Data Sekunder, yaitu data yang diperoleh dari sumber pihak. Biasanya sudah dalam bentuk publikasi seperti data yang diperoleh dari situasi-situasi internet dan data yang berhubungan langsung dengan objek yang diteliti. Dalam hal ini peneliti memperoleh data dari Bank Mandiri Syariah KCP

\footnotetext{
${ }^{10}$ Margono, Metodologi Penelitian Pendidikan (Jakarta: PT. Rineka Cipta, 2010), 158.

${ }^{11}$ Juliansyah, Metodologi Penelitian, 38.
} 
Kuningan berupa Laporan Laba Rugi dan Neraca Sumber data yang diperlukan adalah data primer dan data sekunder.

Dalam penelitian bidang pendidikan, teknik pengumpulan data yang lazim adalah menggunakan instrumen. Dalam menjalankan penelitian data merupakan tujuan utama yang hendak dikumpulkan dengan menggunakan instrument. Instrumen penelitian adalah nafas dari penelitian. Instrumen penelitian adalah sesuatu yang penting dan strategis kedudukannya dalam pelaksanaan penelitian. $^{12}$ Setelah menentukan instrument penelitian, hasil dari instrument penelitian tersebut diuji dengan menggunakan alat statistik, untuk mengetahui apakah instrument tersebut layak tidak digunakan dalam penelitian, dimana terdiri dari dua uji, yaitu uji validitas dan uji reabilitas.

\section{KONSEP DASAR \\ Pembiayaan Mudharabah}

Sedangkan ulama Malikiyyah berpendapat bahwa mudharabah adalah akad perwalian, di mana pemilik harta mengeluarkan hartanya kepada yang lain untuk diperdagangkan dengan pembayaran yang ditentukan (emas dan perak). ${ }^{13}$

Menurut M. Syafi'i Antonio, mudharabah adalah akad kerjasama antara dua pihak dimana pihak pertama (shahibul maal) menyediakan seluruh modal, sedangkan pihak lain (mudharib) menjadi pengelola, dimana keuntungan usaha dibagi dalam bentuk prosentase (nisbah) sesuai kesepakatan, sedangkan apabila rugi ditanggung oleh pemilik modal selama kerugian itu bukan akibat kelalaian si pengelola, apabila kerugian itu diakibatkan oleh kelalaian si pengelola maka si

\footnotetext{
${ }^{12}$ Suharsimi Arikunto, Prosedur Penelitian: Suatu Pendekatan Praktik (Jakarta: Rineka Cipta, 2009), 177.

${ }^{13}$ Hendi Suhendi, Fiqh Muamalah (Bandung: Rajawali Pers, 2007), 136.
}

pengelola harus bertanggung jawab atas kerugian tersebut. ${ }^{14}$

Secara terminology, dikemukakan oleh ulama Hanafiyah yang dikutip oleh Wahbah al-Zuhaily, jual beli adalah saling tukar harta dengan harta melalui cara tertentu atau tukar-menukar sesuatu yang diinginkan dengan yang sepadan melalui cara tertentu yang bermanfaat. $^{15}$ Berdasarkan definisi di atas, maka pada intinya jual beli itu adalah tukar menukar barang. Hal itu telah dipraktikan oleh masyarakat primitive ketika uang belum digunakan sebagai alat tukar-menukar barang, yaitu dengan sistem barter yang dalam terminology fiqh disebut dengan $b a{ }^{\prime} i$ al-muqayyadah. Meskipun jual beli dengan sistem barter telah ditinggalkan, dan diganti dengan sistem mata uang, tetapi terkadang esensi jual beli seperti itu masih berlaku, sekalipun untuk menentukan jumlah barang yang ditukar tetap diperhitungkan dengan nilai mata uang tertentu, misalnya Indonesia membeli spare part kendaraan ke Jepang, maka barang yang di import itu dibayar.

Mudharabah berasal dari kata dharb artinya memukul atau lebih tepatnya proses seseorang memukulkan kakinya dalam perjalanan usaha. $^{16}$ Merupakan akad berbasis bagi hasil, dimana bank syariah menanggung sepenuhnya kebutuhan modal usaha/investasi. ${ }^{17}$ Sebagai suatu bentuk kontrak, mudharabah merupakan akad bagi hasil ketika pemilik dana/modal (pemodal), biasa disebut shahibulmal/rabbul mal, menyediakan modal (100 persen) kepada pengusaha sebagai pengelola, biasa disebut mudharib, untuk melakukan aktivitas

${ }^{14}$ M. Syafi'i Antonio, Bank Syariah dari Teori ke Praktek (Jakarta: Gema Insani Press, 2013), 99.

${ }^{15}$ Abdul Rahman Ghazaly, et.al., Fiqih Muamalat (Jakarta: Kencana, 2010), 67.

${ }^{16}$ Faturrahman Djamil, Penerapan Hukum Perjanjian dalam Transaksi di Lembaga Keuangan Syariah (Jakarta: Sinar Grafika, 2012), 173.

${ }^{17} \mathrm{http}: / / \mathrm{www}$. syariahmandiri.co.id/2010/10/ perbankan-syariah-perkembangan-dan-penjelasan/. Diakses pada tanggal 03 September 2017. 
produktif dengan syarat bahwa keuntungan yang dihasilkan akan dibagi di antara mereka menurut kesepakatan yang ditentukan sebelumnya dalam akad (yang besarnya juga dipengaruhi oleh kekuatan pasar). Shahibul mal (pemodal) adalah pihak yang memiliki modal, tetapi tidak bisa berbisnis, dan mudharib (pengelola atau entrepreneur) adalah pihak yang pandai berbisnis, tetapi tidak memiliki modal. ${ }^{18}$ Aplikasi dari prinsip mudharabah adalah penyimpan atau deposan bertindak sebagai shahibul maal (pemilik modal) dan bank sebagai mudharib (pengelola). Dana tersebut digunakan oleh bank untuk melakukan pembiayaan mudharabah. Hasil usaha ini akan dibagi berdasarkan nisbah yang disepakati. Dalam hal bank mempergunakannya untuk melakukan pembiayaan Mudharabah, maka bank bertanggung jawab penuh atas kerugian yang terjadi. ${ }^{19}$

\section{Dasar Hukum}

Secara umum dasar hukum mudharabah lebih mencerminkan anjuran untuk melakukan usaha, sebagaimana berikut.

Ayat-ayat al-Qur'an yang dapat dijadikan rujukan dasar akad transaksi mudharabah adalah:

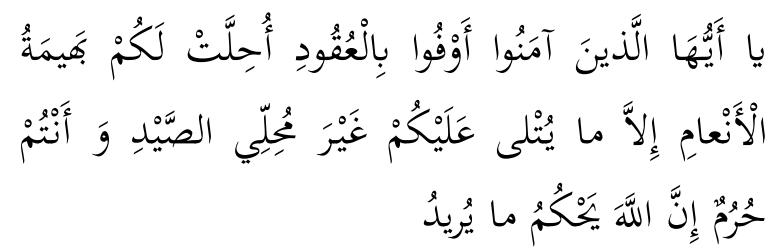

Artinya: Hai orang-orang yang beriman, penuhilah akad-akad itu. Dihalalkan bagimu binatang ternak, kecuali yang akan dibacakan kepadamu.) Yang demikian itu (dengan tidak menghalalkan berburu ketika kamu sedang mengerjakan haji. Sesungguhnya Allah

${ }^{18}$ Ascarya, Akad dan Produk Bank Syariah, (Jakarta: Rajawali Pers, 2011), 60.

${ }^{19}$ Abdul Manan, Hukum Ekonomi Syariah dalam Perspektif Kewenangan Peradilan Agama (Jakarta: Kencana, 2011), 20. menetapkan hukum-hukum menurut yang dikehendaki-Nya. ${ }^{20}$

Mudharabah atau qiradh termasuk salah satu bentuk akad syirkah (perkongsian). Istilah lain mudharabah digunakan oleh orang Irak, sedangkan orang Hijaz menyebutnya dengan istilah qiradh. Dengan demikian, mudharabah dan qiradh adalah istilah maksud yang sama.

Mudharabah adalah pembiayaan yang disalurkan oleh Bank Syariah kepada pihak lain untuk suatu usaha yang produktif. ${ }^{21}$ Mudharabah termasuk juga perjanjian antara pemilik modal (uang dan barang) dengan pengusaha dimana pemilik modal bersedia membiayai sepenuhnya suatu usaha dan pengusaha setuju untuk mengelola proyek tersebut dengan bagi hasil sesuai dengan perjanjian. Di samping itu mudharabah juga berarti suatu pernyataan yang mengandung pengertian bahwa seseorang memberi modal niaga kepada orang lain agar modal itu diniagakan dengan perjanjian keuntungannya dibagi antara dua belah pihak sesuai perjanjian, sedang kerugian ditanggung oleh pemilik modal.

\section{Jenis-jenis Pembiayaan Mudharabah}

Secara umummudharabah terbagi kepada dua jenis, yaitu mudharabah muthlaqah (general investment) dan mudharabah muqayyadah (special investment).

1. Mudharabah Muthlaqah

Mudharabah muthlaqah adalah bentuk kerja sama antara penyedia modal (shahibul maal) dan pengelola modal (mudharib) yang cakupannya sangat luas dan tidak dibatasi oleh spesifikasi jenis usaha, waktu, dan daerah bisnis. Karakteristik jenis simpanan mudharabah Muqayyadah ini sebagai berikut:

\footnotetext{
${ }^{20}$ QS. Al-Maidah (5): 1.

${ }^{21}$ Rizal Yahya, Akuntansi Perbankan Syariah Teori dan Praktek Kontemporer (Jakarta: Salemba Empat, 2009), 122.
} 
a. Pemilik dana wajib menetapkan syarat tertentu yang harus diikuti oleh bank wajib membuat akad yang mengatur persyaratan penyaluran dana simpanan khusus.

b. Bank wajib memberitahukan kepada pemilik dana mengenai nisbah dan tata cara pemberitahuan keuntungan dan/ atau pembagian keuntungan secara risiko yang dapat menimbulkan dari penyimpanan dana. Apabila sudah tercapai kesepakatan, maka hal tersebut harus dicantumkan dalam akad.

c. Sebagai bukti simpanan, bank menerbitkan bukti simpanan khusus. Bank wajib memisahkan dana dari rekening lainnya.

d. Untuk deposito mudharabah, bank wajib memberikan sertifikat atau tanda penyimpanan (bilyet) deposito kepada deposan (penyimpanan). ${ }^{22}$

2. Mudharabah Muqayyadah

Mudharabah muqayyadah atau disebut juga dengan istilah restricted mudharabah atau specified mudharabah adalah kebalikan dari mudharabah muthlaqah, yaitu mudharib dibatasi dengan batasan jenis usaha, waktu, dan tempat usahanya. Dengan adanya pembatasan tersebut seringkali mencerminkan kecenderungan umum shahibul maal dalam memasuki jenis dunia usahanya. ${ }^{23}$

\section{Rukun dan Syarat Mudharabah}

Rukun mudharabah adalah pemodal, pengelola, modal, nisbah keuntungan, dan shighat atau akad. Syarat-syarat mudharabah adalah sebagai berikut.

1. Pemodal dan Pengelola

\footnotetext{
${ }^{22}$ Abdul Manan, Hukum Ekonomi Syariah dalam Perspektif kewenangan peradilan agama, 21.

${ }^{23}$ Faturrahman Djamil, Penerapan Hukum Perjanjian dalam Transaksi di Lembaga Keuangan Syariah, 174.
}
a. Pemodal dan pengelola harus mampu melakukan transaksi dan sah secara hukum
b. Keduanya harus mampu bertindak sebagai wakil dan kafil dari masing- masing pihak.
c. Shighat yang dilakukan bisa secara eksplisit dan implisit yang menunjukkan tujuan akad.
d. Sah sesuai dengan syarat-syarat yang diajukan dalam penawaran, dan akad bisa dilakukan secara lisan atau verbal, secara tertulis maupun ditandatangani.

2. Modal

Modal adalah sejumlah uang yang diberikan oleh penyedia dana kepada pengelola untuk tujuan menginvestasikannya dalam aktivitas mudharabah. Untuk itu, modal disyaratkan harus:

a. Harus berbentuk tunai bukan piutang (namun sebagian ulama membolehkan modal mudharabah berbentuk aset perdagangan, misalnya inventory);

b. Harus diserahkan kepada mudharib untuk memungkinkannya melakukan usaha.

3. Keuntungan

Adalah jumlah yang didapat sebagai kelebihan dari modal. Keuntungan adalah tujuan akhir mudharabah. Keuntungan dipersyaratkan sebagai berikut.
a. Harus dibagi untuk kedua belah pihak.
b. Pembagian keuntungan harus dihasilkan nantinya. dinyatakan dalam persentase dan keuntungan yang mungkin
c. Rasio persentase (nisbah) harus dicapai melalui negosiasi dan dituangkan dalam kontrak.
d. Waktu pembagian keuntungan dilakukan setelah mudharib mengembalikan seluruh (atau


sebagian) modal kepada shahibul mal.

e. Jika jangka waktu akad mudharabah relatif lama, nisbah keuntungan dapat disepakati untuk ditinjau dari waktu ke waktu.

f. Jika penentuan keuntungan dihitung berdasarkan keuntungan kotor (gross profit), biaya-biaya yang timbul disepakati oleh kedua belah pihak, karena dapat mempengaruhi nilai keuntungan. $^{24}$

4. Ketentuan-ketentuan dalam Mudharabah

a. Ketentuan Umum Mudharabah Pembatasan waktu mudharabah. Beberapa ulama berpandangan boleh melakukan pembatasan mudharabah pada periode tertentu. Dilarang membuat kontak yang tergantung kepada sebuah kejadian pada masa yang akan datang, karena mengandung unsur ketidakpastian.

b. Jumlah dalam Mudharabah

Pada dasarnya akad mudharabah adalah akad yang bersifat kepercayaan (trust). Karena itu, dalam mudharabah, menurut sebagian ulama, pemilik dana tidak diperkenankan meminta jaminan sebagaimana jaminan (rahn) dalam transaksi utang-piutang. Sedangkan menurut sebagian ulama lain, jaminan dapat diminta oleh pemilik dana/pemodal kepada pihak pengelola dana dan atau kepada pihak ketiga berupa agunan risiko. Kebolehan pengambilan jaminan tersebut didasarkan pada asumsi si mudharib tidak mustahil melakukan pelanggaran batas atau menyalahi ketentuan yang disepakati, atau disebut dengan jaminan khianat

${ }^{24}$ Faturrahman Djamil, Penerapan Hukum Perjanjian dalam Transaksi di Lembaga Keuangan Syariah, 175-176. (moral hazard) atau jaminan kemungkinan adanya pelanggaran.

Hal mana juga diakui dalam Fatwa MUI No. 07/DSN-MUI/IV/2000 tentang Pembiayaan Mudharabah (Qiradh), bahwa:

Pada prinsipnya dalam pembiayaan mudharabah tidak ada jaminan, namun agar mudharib tidak melakukan penyimpangan. LKS dapat meminta jaminan dari mudharib atau pihak ketiga. Jaminan ini hanya dapat dicairkan apabila mudharib terbukti melakukan pelanggaran terhadap hal-hal yang telah disepakati bersama dalam akad. ${ }^{25}$

5. Kewajiban, Hak, dan Tanggung Jawab Shahibul Maal dalam Mudharabah

Pada hakikatnya, kewajiban utama dari shahibul al-maal ialah menyerahkan modal mudharabah kepada mudharib. Apabila hal itu tidak dilakukan, maka perjanjian mudharabah menjadi tidak sah. Shahibul al-maal berkewajiban untuk menyediakan dana yang dipercayakan kepada mudharib untuk tujuan membiayai suatu proyek atau suatu kegiatan usaha. Shahib al-maal tidak diperkenankan mengolah proyek atau kegiatan usaha yang dibiayai olehnya. Pengelolaan proyek atau kegiatan usaha itu sepenuhnya dilakukan oleh mudharib. Paling jauh shahib almaal hanya boleh memberikan saransaran tertentu kepada mudharib dalam menjalankan atau mengelola proyek atau usaha tersebut. Dengan demikian, shahib al-maal hanya berstatus sebagai sleeping partner. Shahib al-maal berhak untuk melakukan pengawasan untuk memastikan bahwa mudharib menaati syarat-syarat dan ketentuan-ketentuan

${ }^{25}$ Faturrahman Djamil, Penerapan Hukum Perjanjian dalam Transaksi di Lembaga Keuangan Syariah,176-177. 
perjanjian mudharabah. Jual beli bathil (batal) adalah jual beli yang tidak sesuai dengan rukun dan akadnya (ketentuan asal/pokok dan sifatnya). Seperti jual beli yang dilakukan oleh orang yang tidak sesuai (karena tidak sesuai dengan syarat dan rukun), contohnya: akad yang dilakukan anak kecil yang belum mumayis dan orang gila atau jual beli sesuatu yang tidak berharga seperti bangkai, atau jual beli barang yang dilarang seperti khamar. Menurut Abu Hanifah, jual beli yang batal tidak menjadikan pertukaran kepemilikan karena rusak jual belinya.

\section{Aplikasi Mudharabah dalam Perbankan}

Sejauh ini, skema Mudharabah yang telah kita bahas adalah skema yang berlaku antara dua pihak saja secara langsung, yakni shahib al-mal berhubungan langsung dengan mudharib. Skema ini adalah skema standar yang dapat dijumpai dalam kitabkitab klasik fiqh Islam. Dan inilah sesungguhnya praktik mudharabah yang dilakukan oleh nabi dan para sahabat serta umat muslim sesudahnya. Dalam kasus ini, yang telah terjadi adalah investasi langsung (direct financing) antara shahib al-maal (sebagai surplus unit) dengan mudharib (sebagai direct unit). ${ }^{26}$ Dalam perbankan syari'ah biasanya diterapkan pada produkproduk pembiayaan dan pendanaan. Sedangkan pada sisi penghimpunan dana mudharabah diterapkan pada: dalam direct financing seperti ini, peran bank sebagai lembaga perantara (intermediary) tidak ada.

Mudharabah klasik seperti ini memiliki ciri-ciri khusus, yakni bahwa biasanya hubungan antara shahib al-mal dengan mudharib merupakan hubungan personal dan langsung serta dilandasi oleh rasa saling percaya (amanah). Shahib al-mal hanya mau menyerahkan modalnya kepada

${ }^{26}$ Surplus unit adalah pihak-pihak yang memiliki kelebihan dana (pemilik modal), sedangkan deficit unit adalah pihak-pihak yang membutuhkan dana untuk usaha (pengusaha). orang yang ia kenal dengan baik profesionalitas maupun karakternya.

\section{Pengertian Return On Investment}

Hasil pengembalian investasi atau lebih dikenal dengan nama Return On Invesment (ROI) atau return on total investment merupakan rasio yang menunjukkan hasil (return) atas jumlah aktiva yang digunakan dalam perusahaan. ROI juga merupakan suatu ukuran tentang efektivitas manajemen dalam mengelola investasinya. Di samping itu, hasil pengembalian investasi menunjukkan produktivitas dari seluruh dana perusahaan, baik modal pinjaman maupun modal sendiri. Semakin kecil (rendah) rasio ini, semakin kurang baik, semakian pula sebaliknya. Artinya rasio ini digunakan untuk mengukur efektivitas dari keseluruhan operasi perusahaan.

ROI juga merupakan salah satu bentuk rasio profitabilitas yang menunjukkan hasil (return) atas jumlah aktiva yang digunakan dalam perusahaan atau suatu ukuran tentang aktivitas manajemen. ${ }^{27}$

Return On Invesment juga disebut sebagai alat pengukur yang efektif dari keseluruhan operasi perusahaan. Dimana rumus yang digunakan untuk menghitung suatu tingkat pengembalian investasi atau return on investment adalah:

$$
\begin{gathered}
\text { Return On Investment }= \\
\frac{\text { Earning After Interst and Tax }}{\text { Total Aktiva }} \times 100 \% \\
\text { atau }
\end{gathered}
$$$$
R O I=\frac{\text { Penjualan }}{\text { Total Aktiva }} x \frac{\text { Laba setelah Pajak }}{\text { Penjualan }}
$$

Return on Invesment sebagai alat pengukur kinerja pusat laba memiliki dua manfaat, yaitu:

1. Return on Invesment dapat mengukur efisiensi penggunaan modal, efisiensi,

${ }^{27}$ Kasmir, Analisis Laporan Keuangan (Jakarta: Rajawali Pers, 2011), 201. 
efisiensi produksi dan efisiensi bagian penjualan.

Return on Invesment untuk dapat membandingkan efisiensi suatu bagian dengan bagian yanng lain didalam perusahaan yang bersangkutan.

\section{Pengaruh Pembiayaan Mudharabah terhadap Return On Investment}

Pembiayaan Bagi Mudharabah akan mempengaruhi pendapatan laba atau keuntungan perusahaan. Hal ini dikarenakan salah satu faktor dari Return On Invesment di dapat dari pembiayaan bagi hasil yang diberikan untuk pembiayaan Mudharabah.

Penyaluran pembiayaan yang besar akan menghasilkan pendapatan yang besar pula. Pada akhirnya, pendapatan yang berasal dari kegiatan utama bank yaitu penyaluran pembiayaan tersebut akan berpengaruh terhadap tingkat Return On Invesment yang diperoleh oleh bank syariah. Tingkat pembiayaan Mudharabah memiliki pengaruh yang relatif baik terhadap tingkat return on invesment dan efisiensi biaya bank syariah karena pada pembiayaan Mudharabah tingkat keuntungan bank ditentukan dari besarnya keuntungan usaha dengan prinsip bagi hasil dimana keuntungan ditentukan oleh nisbah bagi hasil yang disepakati.

\section{PEMBAHASAN DAN DISKUS}

Setelah melakukan berbagai pengolahan dan analisis terhadap data yang diperoleh, penulis mendapatkan gambaran mengenai variabel bebas yang terdiri dari pendapatan bagi hasil pembiayaan mudharabah serta gambaran mengenai variabel terikat yaitu Return On Investment dan pengaruah variabel bebas tersebut terhadap variabel terikat Return On Investment pada Bank Mandiri Syariah KCP Kuningan untuk tahun 2009 sampai dengan tahun 2015 sebagai berikut:
Gambaran Pendapatan Bagi Hasil
Pembiayaan Mudharabah

\begin{tabular}{lc}
\hline \multicolumn{1}{c}{ Tahun } & $\begin{array}{c}\text { Pembiayaan } \\
\text { Mudharabah (X1) }\end{array}$ \\
\hline triwulan 1 2009 & $4.66 \%$ \\
\hline triwulan 2 2009 & $4.91 \%$ \\
\hline triwulan 3 2009 & $4.94 \%$ \\
\hline triwulan 4 2009 & $4.13 \%$ \\
\hline triwulan 1 2010 & $3.96 \%$ \\
\hline triwulan 2 2010 & $3.71 \%$ \\
\hline triwulan 3 2010 & $3.95 \%$ \\
\hline triwulan 4 2010 & $3.87 \%$ \\
\hline triwulan 1 2011 & $3.66 \%$ \\
\hline triwulan 2 2011 & $3.57 \%$ \\
\hline triwulan 3 2011 & $3.61 \%$ \\
\hline triwulan 4 2011 & $3.21 \%$ \\
\hline triwulan 1 2012 & $3.30 \%$ \\
\hline triwulan 2 2012 & $3.70 \%$ \\
\hline triwulan 3 2012 & $3.56 \%$ \\
\hline triwulan 4 2012 & $3.59 \%$ \\
\hline triwulan 1 2013 & $3.44 \%$ \\
\hline triwulan 2 2013 & $3.60 \%$ \\
\hline triwulan 3 2013 & $3.04 \%$ \\
\hline triwulan 4 2013 & $3.38 \%$ \\
\hline triwulan 1 2014 & $3.29 \%$ \\
\hline triwulan 2 2014 & $3.33 \%$ \\
\hline triwulan 3 2014 & $3.13 \%$ \\
\hline triwulan 4 2014 & $3.06 \%$ \\
\hline triwulan 1 2015 & $3.25 \%$ \\
\hline triwulan 2 2015 & $2.97 \%$ \\
\hline triwulan 3 2015 & $3.21 \%$ \\
\hline triwulan 4 2015 & $3.55 \%$ \\
\hline
\end{tabular}

Gambaran pembiayaan mudharabah Bank Mandiri Syariah KCP Kuningan selama tahun 2009 sampai dengan tahun 2015 cenderung mengalami peningkatan.

Pembiayaan tersebut disebabkan oleh semakin banyaknya pendapatan bagi hasil pembiayaan mudharabah yang dikeluarkan oleh Bank Mandiri Syariah KCP Kuningan, seiring dengan banyaknya minat masyarakat yang lebih memilih melakukan pembiayaan di Bank syariah khususnya di Bank Mandiri Syariah KCP Kuningan karena prosesnya mudah dan tidak memberatkan nasabah. Selain itu, pendapatan bagi hasil pembiayaan 
mudharabah yang diberikan oleh Bank Mandiri Syariah KCP Kuningan diaplikasikan dengan bagi hasil yang proporsional.

\begin{tabular}{|c|c|}
\hline $\begin{array}{l}\text { Gambaran Retu } \\
\text { Mandiri Syariah }\end{array}$ & $\begin{array}{l}\text { On Investment } \\
\text { CP Kuningan }\end{array}$ \\
\hline Tahun & $\begin{array}{c}\text { Return On } \\
\text { Investment }(Y)\end{array}$ \\
\hline triwulan 12009 & $0,36 \%$ \\
\hline triwulan 22009 & $0,67 \%$ \\
\hline triwulan 32009 & $1,022 \%$ \\
\hline triwulan 42009 & $1,32 \%$ \\
\hline triwulan 12010 & $0,36 \%$ \\
\hline triwulan 22010 & $0,074 \%$ \\
\hline triwulan 32010 & $1,14 \%$ \\
\hline triwulan 42010 & $1,28 \%$ \\
\hline triwulan 12011 & $0,37 \%$ \\
\hline triwulan 22011 & $0,7 \%$ \\
\hline triwulan 32011 & $0,94 \%$ \\
\hline triwulan 42011 & $1,13 \%$ \\
\hline triwulan 12012 & $0,38 \%$ \\
\hline triwulan 22012 & $0,79 \%$ \\
\hline triwulan 32012 & $1,16 \%$ \\
\hline triwulan 42012 & $1,48 \%$ \\
\hline triwulan 12013 & $0,46 \%$ \\
\hline triwulan 22013 & $0,62 \%$ \\
\hline triwulan 32013 & $0,76 \%$ \\
\hline triwulan 42013 & $1,01 \%$ \\
\hline triwulan 12014 & $1,77 \%$ \\
\hline triwulan 22014 & $0,66 \%$ \\
\hline triwulan 32014 & $0,8 \%$ \\
\hline triwulan 42014 & $0,17 \%$ \\
\hline triwulan 12015 & $0,81 \%$ \\
\hline triwulan 22015 & $0,55 \%$ \\
\hline triwulan 32015 & $0,42 \%$ \\
\hline triwulan 42015 & $0,56 \%$ \\
\hline
\end{tabular}

Gambaran profitabilitas Bank Mandiri Syariah KCP Kuningan selama tahun 2009 sampai dengan tahun 2015 cenderung mengalami fluktuatif. Rata-rata return on investment setiap tahunnya mengalami kenaikan dan penurunan yang fluktuatif, seiring dengan perkembagan pendapatan bagi hasil pembiayaan mudharabah.
Peningkatan tersebut disebabkan dari pendapatan bagi hasil pembiayaan mudharabah sehingga Bank Mandiri Syariah KCP Kuningan dapat meningkatkan tingkat pengembalian investasi atau return on investment (ROI).

\section{Pengaruh Pembiayaan Mudharabah terhadap Return On Investment}

Hasil analisis regresi linear sederhana diperoleh regresi dari $\mathrm{Y}=-1.232+0.554 \mathrm{X}$. Persamaan tersebut menunjukkan bahwa apabila pembiayaan mudharabah mengalami kenaikan 1 rupiah maka return on investment $(\mathrm{Y})$ akan mengalami kenaikan sebesar 0.554 dari pembiayaan mudharabah. Koefisien bernilai positif artinya terjadi hubungan positif antara pembiayaan mudharabah dengan return on investment, semakin meningkat pembiayaan mudharabah maka semakin naik peroleh return on investment.

Hasil analisis koefisien determinasi (R Square) sebesar 0,494 . hal ini berarti return on investment dipengaruhi oleh pembiayaan mudharabah sebesar 49,4\% sisanya $50,6 \%$ dipengaruhi oleh faktor lain seperti pembiayaan murabahah, pembiayaan musyarakah, pembiayaan istishna, pembiyaan ijarah, pendapatan lainlain dan beban-beban operasional.

Hasil uji hipotesis diperoleh karena $\mathrm{F}_{\text {hitung }} 25,380>\mathrm{F}_{\text {tabel }}$ 4,23 maka Ho ditolak dan Ha diterima, artinya pembiayaan mudharabah berpengaruh signifikan terhadap return on investment.

\section{KESIMPULAN}

Berdasarkan hasil penelitian dan pembahasan mengenai pengaruh pembiayaan Mudharabah terhadap Return On Investment pada Bank Mandiri Syariah KCP Kuningan penulis dapat menarik 3 (tiga) kesimpulan, yaitu pertama, gambaran pembiayaan Mudharabah Bank Mandiri Syariah KCP Kuningan selama 2009 sampai dengan tahun 2015 cenderung mengalami peningkatan. 
Kedua, gambaran Return On Investment Bank Mandiri Syariah KCP Kuningan selama tahun 2009 sampai dengan tahun 2015 mengalami kenaikan dan penurunan yang fluktuatif, seiring dengan perkembangan pendapatan bagi hasil pembiayaan Mudharabah.

Dan ketiga, dari hasil uji signifikansi secara parsial Pendapatan Bagi Hasil Pembiayaan Mudharabah berpengaruh positif dan signifikan terhadap Return On Investment.

\section{DAFTAR PUSTAKA}

Ismail. Perbankan Syariah. Jakarta: Kencana, 2010.

Www.Ekonomi.kabo.biz/2012/01/return-oninvestment-roi.html/m=1.

Fatwa Dewan Syariah Nasional No. 7 tentang Mudharabah.

Arifin. "Pengaruh Margin Murabahah dan Bagi Hasil atas Pembiayaan Terhadap Tingkat Return On Investment pada perbankan Syariah". Skripsi, Fakultas Syari'ah dan Hukum UIN Sunan Kalijaga Yogyakarta, 2010.

Purnaningsih, Imas. "Pengaruh Tingkat Pendapatan Bagi Hasil Pembiayaan Mudharabah dan Pembiayaan Musyarakah Terhadap Profitabilitas pada Bank Muamalat Indonesia Tbk”. Skripsi, Universitas Kuningan, 2012.

Juliansyah. Metodologi Penelitian. Jakarta: Kencana Prenada Media Group, 2010.

Asnawi, Nur dan Masyhuri. Metodologi Riset Manajemen Pemasaran. Malang: UIN-Malang Press, 2009.

Abdurahman, Maman. Analisis Korelasi, Regresi, dan Jalur dalam Penelitian. Bandung: CV Pustaka Setia, 2011.

Margono. Metodologi Penelitian Pendidikan. Jakarta: PT. Rineka Cipta, 2010.

Arikunto, Suharsimi. Prosedur Penelitian: Suatu Pendekatan Praktik. Jakarta: Rineka Cipta, 2009.
Suhendi, Hendi. Fiqh Muamalah. Bandung: Rajawali Pers, 2007.

Antonio, M. Syafi'i. Bank Syariah dari Teori ke Praktek. Jakarta: Gema Insani Press, 2013.

Ghazaly, Abdul Rahman et.al., Fiqih Muamalat. Jakarta: Kencana, 2010.

Djamil, Faturrahman. Penerapan Hukum Perjanjian dalam Transaksi di Lembaga Keuangan Syariah. Jakarta: Sinar Grafika, 2012.

http://www.syariahmandiri.co.id/2010/10/pe rbankan-syariah-perkembangan-danpenjelasan/.

Ascarya. Akad dan Produk Bank Syariah,. Jakarta: Rajawali Pers, 2011.

Manan, Abdul. Hukum Ekonomi Syariah dalam Perspektif Kewenangan Peradilan Agama. Jakarta: Kencana, 2011.

Yahya, Rizal. Akuntansi Perbankan Syariah Teori dan Praktek Kontemporer. Jakarta: Salemba Empat, 2009.

Kasmir. Analisis Laporan Keuangan. Jakarta: Rajawali Pers, 2011. 